\title{
ArcheoSciences
}

Revue d'archéométrie

\section{Helium, uranium and thorium analyses of ancient and modern gold objects: estimates of their time of manufacturing}

Analyse de l'hélium, de l'uranium et du thorium dans des objets anciens et modernes en or : estimation de leur date de fabrication

Otto Eugster, Ernst Pernicka, Michael Brauns, Alex Shukolyukov, Valerie Olive and Stefan Roellin

\section{OpenEdition}

\section{Journals}

\section{Electronic version}

URL: https://journals.openedition.org/archeosciences/2017

DOI: 10.4000/archeosciences.2017

ISBN: 978-2-7535-1598-7

ISSN: $2104-3728$

Publisher

Presses universitaires de Rennes

\section{Printed version}

Date of publication: 31 December 2009

Number of pages: $59-69$

ISBN: 978-2-7535-1181-1

ISSN: 1960-1360

Electronic reference

Otto Eugster, Ernst Pernicka, Michael Brauns, Alex Shukolyukov, Valerie Olive and Stefan Roellin,

"Helium, uranium and thorium analyses of ancient and modern gold objects: estimates of their time of manufacturing", ArcheoSciences [Online], 33 | 2009, Online since 09 December 2012, connection on 01 February 2022. URL: http://journals.openedition.org/archeosciences/2017 ; DOI: https://doi.org/ 10.4000/archeosciences.2017 


\title{
Helium, uranium and thorium analyses of ancient and modern gold objects: estimates of their time of manufacturing
}

\author{
Analyse de l'hélium, de l'uranium et du thorium dans des objets anciens \\ et modernes en or : estimation de leur date de fabrication
}

\author{
Otto Eugster*, Ernst Pernicka**, Michael Brauns**, Alex Shukolyukov***, \\ Valerie Olive**** and Stefan Roellin*****
}

\begin{abstract}
Authenticating archaeological gold objects is a major problem, as gold is probably the most difficult material in terms of detecting modern forgeries. In 1996 we published the results of the study of faked and genuine gold crystals from the Santa Elena gold mine in Venezuela, and demonstrated that the U/Th - He dating method is a powerful tool for detecting forgeries among gold objects. U and Th decay by emitting $\mathrm{He}$ atoms that remain stored in gold. By measuring $\mathrm{U}$, Th, and $\mathrm{He}$, the time when the He trapping process started can be determined. In the 1996 publication we also mentioned that the same method can be applied to ancient gold objects, in order to determine the time when they experienced their last melting process and, thus, to verify their antiquity. In the present work we report on a systematic and quantitative study of $\mathrm{He}, \mathrm{U}$, and $\mathrm{Th}$ in a large number of ancient and modern gold objects.

Résumé : L'authentification d'objets en or est un problème majeur, car l'or est probablement le matériau le plus difficile quand il s’agit de détecter des contrefaçons modernes. En 1996 nous avons publié les résultats d'une étude de cristaux d'or faux et authentiques de la mine d'or de Santa Elena, au Venezuela, et nous avons montré que la méthode de datation U/Th - He est un outil puissant pour détecter les contrefaçons dans le cas des objets en or. La décroissance de l'U et du Th se fait par émission d'atomes d'He qui restent stockés dans l'or. La mesure de l'U, du Th et de l'He permet de déterminer le moment de départ du processus de piège de l'He. Dans notre publication de 1996, nous avons aussi mentionné que cette même technique peut être appliquée aux objets d'or anciens, de façon à déterminer le moment correspondant à leur dernière fonte et ainsi de vérifier leur ancienneté. Dans cet article nous présentons une étude systématique et quantitative de l'He, de l'U et du Th dans un large nombre d'objets d'or anciens et modernes.
\end{abstract}

Keywords: Antique gold, forgeries, helium, uranium, thorium, mass spectrometry.

Mots-clés : or ancien, contrefaçons, hélium, uranium, thorium, spectrométrie de masse.

\footnotetext{
* Physics Institute, University of Bern - Sidlerstrasse 5, 3012 Bern, Switzerland. (eugster@space.unibe.ch)

**Curt-Engelhorn-Zentrum Archäometrie - C5, Zeughaus, 68159 Mannheim, Germany. (ernst.pernicka@cez-archaeometrie.de), (michael.brauns@ cez-archaeometrie.de)

*** Scripps Institution of Oceanography, UCSD - 9500 Gilman Drive, La Jolla, CA 92093, USA. (ashukolyukov@ucsd.edu)

**** SUERC - Ranking Avenue, East Kilbride G75 0QF, Scotland. (v.olive@suerc.gla.ac.uk)

***** Bundesamt für Bevölkerungsschutz - Labor Spiez, 3700 Spiez, Switzerland. (stefan.roellin@babs.admin.ch)
} 


\section{INTRODUCTION}

When gold crystals are formed in the Earth's crust, other elements, such as $\mathrm{U}$, are incorporated into the crystal lattice. Thus, gold from mines and from river beds always contains traces of $U$ and Th. The three long-lived isotopes ${ }^{238} \mathrm{U},{ }^{235} \mathrm{U}$, and ${ }^{232} \mathrm{Th}$ decay to $\mathrm{Pb}$ by emitting $\alpha$-particles. An $\alpha$-particle is the nucleus of the ${ }^{4} \mathrm{He}$ atom, so when two electrons combine with an $\alpha$-particle, a ${ }^{4} \mathrm{He}$ atom is formed. The ${ }^{4} \mathrm{He}$ atoms remain stored in the metal. A fourth long-lived radionuclide, ${ }^{147} \mathrm{Sm}$, also disintegrates by $\alpha$-decay, but contributes in antique gold objects only a few percent to the total radiogenic (produced by radioactive decay) ${ }^{4} \mathrm{He}$. Because gold is highly retentive of this gas up to about $500{ }^{\circ} \mathrm{C}$, the $\mathrm{He}$ atoms remain trapped in the metal. Beginning with 1992, we have studied these characteristics in numerous natural gold samples from all over the world (for references, see Eugster et al., 2009). In Table 1, the data on $\mathrm{He}, \mathrm{U}$, and Th obtained for placer gold samples are provided.

In a subsequent work (Eugster, 1996), we presented results on the study of genuine and faked gold crystals (Fig. 1) from the Santa Elena gold mine in Venezuela. The data for the genuine samples provided in the aforementioned paper and new data obtained for three samples of genuine crystals analyzed recently (Table 1) yield an estimated age of 240 million years $(\mathrm{Ma})$. This time may be consistent with the Palaeozoic-Mesozoic $(542-65.5 \mathrm{Ma})$ intrusive rocks of the gold mineralisation (Beda Hofmann, private communication). In Eugster (1996), we also presented He, U, and Th data for faked gold crystals that appeared on the mineral market. These data, complemented with two new He analyses and Th concentrations obtained recently, demonstrate that the fake crystals are undatably young, the He concen-

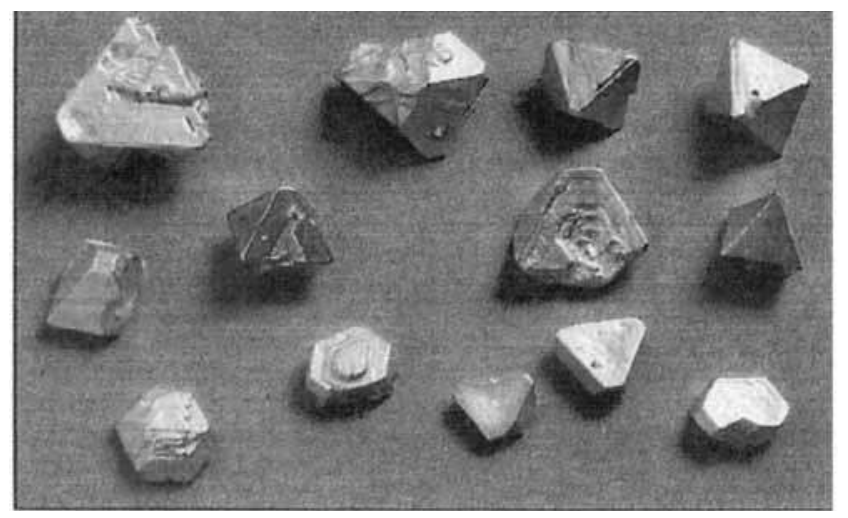

Figure 1: Faked octahedral gold crystals of up to 30 grams, purported to originate from the Santa Elena gold mine (Venezuela). Figure 1 : Faux cristaux en or octogonal de plus de $30 \mathrm{~g}$, dont la provenance supposée est la mine d'or de Santa Elena (Venezuela). trations being below the detection limit of the mass spectrometer.

The He quantities in samples of art objects are extremely small for two reasons: (1) the time during which He has accumulated is usually only a few thousand years, in contrast to geological gold that formed millions of years ago; (2) only very small samples of a valuable object are available for the analyses. Inspired by our initial publications, specialists in the scientific investigation of ancient metals saw the potential for additional authenticity studies. Kossolapov et al. (1999) and Kossolapov and Chugunova (2002), working at the State Hermitage Museum in St. Petersburg, Russia, collaborated with the company SPECTRON ANALYT in St. Petersburg to build a highly sensitive mass spectrometer and measured the He concentrations in a selection of ancient gold objects.

The present work is a continuation of our earlier investigation of a number of antique gold objects (Eugster $e t$ al., 2009). Some objects described in this earlier publication are also included in the present work, because we obtained additional $\mathrm{He}$ data for them, and, in particular, because $U$ and Th analyses were performed for these objects, for which, in our earlier investigation, we had to employ average $U$ and Th values.

\section{INVESTIGATED OBJECTS}

\section{Test objects of modern manufacture}

In the course of our experimental work, we repeatedly analyzed samples from gold objects of modern manufacture to verify the absence or low abundance of radiogenic $\mathrm{He}$ expected for the short time of $U$ and Th decay since their manufacture. Table 2 lists the three objects used for this purpose. Results for these objects have already been reported in our earlier publication (Eugster et al., 2009). Because in the meantime additional He results were obtained and the $U$ and Th measurements had not been completed earlier, we will discuss the results for these objects. The $\mathrm{He}$ concentrations in eight samples of typically $10 \mathrm{mg}$ of a gold coin Napoléon III, minted in 1857, were measured. New results for a wedding ring of 1886 are presented, as $\mathrm{U}$ and Th concentrations are now known, allowing us to verify the recent date of manufacture. Finally, we intended to confirm the absence of $\mathrm{He}$ in 11 samples of a commercial gold wire, and we also determined its $U$ and Th concentrations. 


\begin{tabular}{lccccc}
\hline & $\begin{array}{c}{ }^{4} \mathrm{He} \\
10^{10} \mathrm{atoms} / \mathrm{g}\end{array}$ & $\begin{array}{c}{ }^{20} \mathrm{Ne} \\
10^{10} \text { atoms/g }\end{array}$ & $\begin{array}{c}\mathrm{U} \\
\mathrm{ppb}\end{array}$ & $\begin{array}{c}\mathrm{Th} \\
\mathrm{ppb}\end{array}$ & $\begin{array}{c}\text { Estimated * } \\
\text { U,Th }{ }^{4} \mathrm{He} \text { age } \\
\text { (million years) }\end{array}$ \\
\hline $\begin{array}{l}\text { Placer gold } \\
\text { Grosse Fontanne river } \\
\text { Switzerland }\end{array}$ & $75000^{1}$ & 0.48 & 220 & 220 & 850 \\
$\begin{array}{l}\text { Gold crystal, genuine } \\
\text { Santa Elena gold } \\
\text { mine (Venezuela) }\end{array}$ & $17000^{2.3}$ & $0.054^{2.3}$ & $12.1^{3}$ & $40^{5}$ & 240 \\
$\begin{array}{l}\text { Gold crystal, fake } \\
\text { purported to originate } \\
\text { from the Santa Elena } \\
\text { gold mine }\end{array}$ & $<0.003^{4}$ & $0.027^{2.3}$ & & & \\
\hline
\end{tabular}

Table 1: Noble gases, U and Th concentrations and estimated ages of geologic gold samples. Tableau 1: Gaz rares, concentrations d'U et Th, et âges estimés d'échantillons géologiques en or.
Experimental error of placer gold and genuine Santa Elena gold: 5-10\%; of fake gold: $30 \%$.

1 Average of 4 analyses; ${ }^{2}$ average of 3 analyses; ${ }^{3}$ Eugster (1996); ${ }^{4}$ average of 2 analyses; ${ }^{5}$ adopted value; ${ }^{6}$ due to sample inhomogeneities, the ages are only estimates.

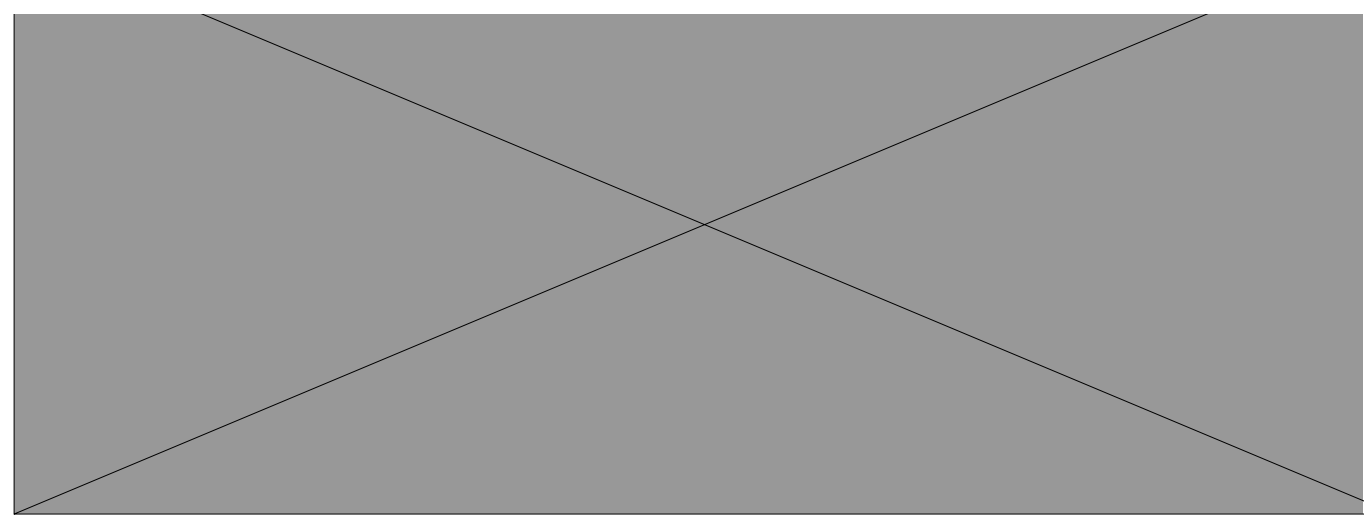

Table 2: Test objects of modern manufacture.

Tableau 2 : Objets de test de fabrication moderne. 


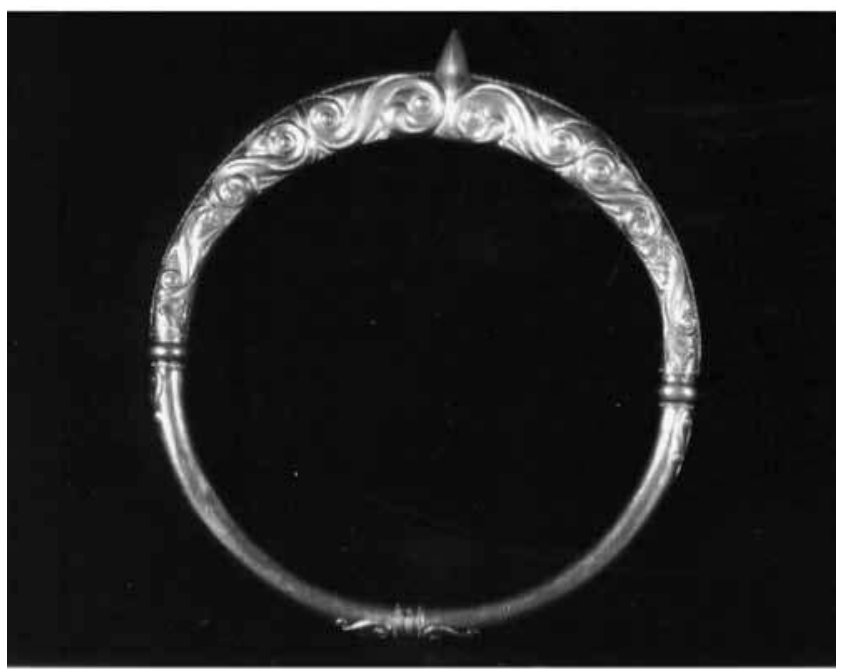

Figure 2: (See colour plate) Gold torc purported to originate from the Hallstatt/La Tène transition period $\left(5^{\text {th }}\right.$ century BC). Diameter: $16.5 \mathrm{~cm}$.

Figure 2: (Voir planche couleur) Torque en or supposément attribué à la période de transition Hallstatt/La Tène (V siècle av. J.-C.). Diamètre: $16,5 \mathrm{~cm}$.

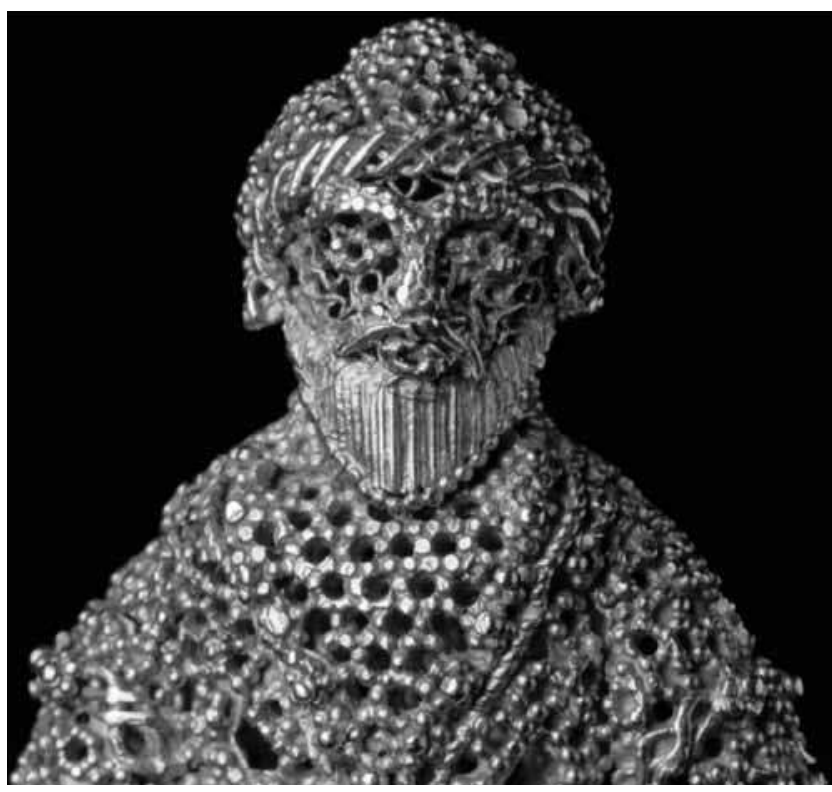

Figure 3: (See colour plate) Golden figurine decorated with granulation. Possible origin: Iran or central Asia $\left(11^{\text {th }}\right.$ or $12^{\text {th }}$ century AD). For size, see text.

Figure 3: (Voir planche couleur) Figurine en or décorée de granulation. Origine possible: Iran ou Asie centrale (XI ou XIII siècle). Pour les dimensions voir texte.

coins), indicating that coins of this type were used by the goldsmith to manufacture the royal ring. Regarding the chemical composition of the gold in the Childebert ring, we refer to Weber (2007), who discussed the results that were

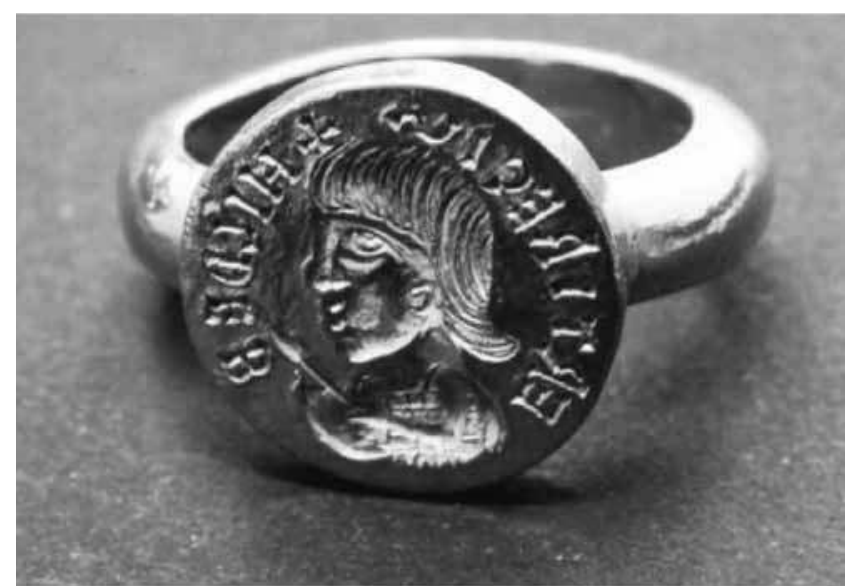

Figure 4: (See colour plate) Signet ring attributed to kings Childebert I or II, of the sixth century Merovingian dynasty of Western Europe.

Figure 4 : (Voir planche couleur) Bague à sceau attribuée au roi Childéric I ou II, de la dynastie Mérovingienne d'Europe Occidentale, v' siècle.

obtained at the Curt-Engelhorn-Zentrum Archäometrie in Mannheim using LA-ICP-MS. In the present work, we report additional data, in particular the $\mathrm{U}$ and Th concentrations for the Childebert ring, which were not yet available for our previous publication.

\section{EXPERIMENTAL METHODS}

For the details of sample preparation and $\mathrm{He}$ analyses we refer to our earlier publication (Eugster et al., 2009). The $\mathrm{U}$ and $\mathrm{Th}$ analyses used in this work were performed by six different laboratories. In most cases, multiple analyses for a particular gold object, and numerous tests and blank measurements had to be carried out. Therefore, the work load would have been too large for a single laboratory, as the $\mathrm{U}$ and Th analyses of gold objects were not the main priority of the respective scientists' activity. Furthermore, two of the collaborators went into retirement in the course of the present work. The following laboratories were involved in this study: (i) Curt-Engelhorn-Zentrum Archäometrie, Mannheim (Ernst Pernicka, Michael Brauns, Boaz Paz), using quadrupole inductively coupled plasma mass spectrometry after electrolytic separation of $U$ and $T h$ from $\mathrm{Au}$ and other metals on graphite electrodes; (ii) Scripps Institution of Oceanography, UCSD, La Jolla, CA (Alex Shukolyukov, Paterno Castillo), using an inductively coupled plasma mass spectrometer (ICP-MS) after chemical separation of $U$ and Th from Au and other metals; (iii) Labor Spiez (Stefan Röllin), digestion of Au samples in aqua regia, direct analy- 
sis of U and Th with an ICP-MS; (iv) Scottish Universities Environmental Research Center (Valerie Olive), using an ICP-MS after chemical separation of U and Th; (v) Institute of Geology, University of Bern (Jan Kramers), using a multicollector inductively coupled plasma mass spectrometer with desolvating nebulizer, after chemical separation of $U$ and $T h$ and addition of a ${ }^{236} \mathrm{U}$ and a ${ }^{229} \mathrm{Th}$ spike; (vi) Department of Chemistry and Biochemistry, University of Bern (Urs Krähenbühl), using an ICP-MS after chemical separation of $U$ and $T h$.

For an inter-laboratory comparison, a large number of different samples of object DL 807 (Table 3) were prepared. In five different laboratories, samples of this ancient gold object were measured for their $U$ concentration, the most important element for He production. The following results were obtained (in case of multiple analyses, the average values are given): $0.9 \mathrm{ppb}$ (laboratory (i), as indicated above), $3.5 \mathrm{ppb}$ (ii), $1.9 \mathrm{ppb}$ (iii), $5.5 \mathrm{ppb}$ (v), $12.8 \mathrm{ppb}$ (vi). The differences in the $U$ concentration obtained by these laboratories are presumably due to sample inhomogeneity. This shows that it is important to analyze the $\mathrm{He}, \mathrm{U}$, and Th concentrations in the same section of the sample.

\section{ReSUlTS AND DISCUSSION}

\section{Objects of modern manufacture}

The results are given in Table 2. The He concentrations for the three objects are extremely low; for the wedding ring of 1886 and the commercial gold wire, they are at or below the detection limit of the mass spectrometer. For the Napoléon coin, we used typically $10 \mathrm{mg}$ of gold material (after etching) to obtain a reliable signal. The age estimate is consistent with the time when the coin was minted.

\begin{tabular}{|c|c|c|c|c|c|c|}
\hline Object and origin (sample Nr.) & $\begin{array}{l}\text { Obtained } \\
\text { from }\end{array}$ & $\begin{array}{l}\text { Reported } \\
\text { century * }\end{array}$ & $\begin{array}{c}\mathrm{He} \\
10^{4} \text { atoms/mg }\end{array}$ & $\begin{array}{r}\mathrm{U} \\
\mathrm{ppb}\end{array}$ & $\begin{array}{r}\text { Th } \\
\text { ppb }\end{array}$ & $\begin{array}{c}\text { Estimated } \\
\mathrm{U}, \mathrm{Th}-{ }^{4} \mathrm{He} \text { age (years) }\end{array}$ \\
\hline $\begin{array}{l}\text { Signet ring of Merowingian king } \\
\text { France (MR 1) }\end{array}$ & 1 & 6th $\mathrm{AD}$ & 10.7 & $3.4^{9}$ & $79^{9}$ & $1460 \pm 400$ \\
\hline Celtic torc, Southern Germany (CT 1) & 2 & 5th BC & 18.5 & $15^{10}$ & $45^{10}$ & $2200 \pm 1100$ \\
\hline Belt chain, Balkan (DL 807) & 3 & 2nd AD & 16.8 & $9.2^{11}$ & $28.6^{11}$ & $3200 \pm 1600$ \\
\hline Ring Arjhan II tomb, Scytia (Scyt 1) & 4 & 7th $\mathrm{BC}$ & 21.3 & $15^{10}$ & $45^{10}$ & $2500 \pm 1200$ \\
\hline Gold object, Black Sea, Russia (JDM 2) & 5 & 6th BC & 16.1 & $4^{9}$ & $69^{9}$ & $2400 \pm 1200$ \\
\hline $\begin{array}{l}\text { Glazed ceramic box, Liao dynasty, } \\
\text { China (083108-8) }\end{array}$ & 2 & $10-12 \mathrm{AD}$ & 12.7 & $7.9^{12}$ & $128.5^{12}$ & $1010 \pm 500$ \\
\hline $\begin{array}{l}\text { Gold cup with boar-shaped handle } \\
\text { Outer Mongolia (2032) }\end{array}$ & 6 & 1st $\mathrm{AD}$ & 1.2 & $0.4^{13}$ & $0.2^{13}$ & $4500 \pm 3000$ \\
\hline Chain, Balkan (DL 808) & 3 & 4 th $\mathrm{AD}$ & 1.2 & $0.8^{15}$ & $<0.8^{15}$ & $2700 \pm 1300$ \\
\hline Gold bowl, origin u.k. (AA) & 5 & 3-4th BC & 8.0 & $6.3^{11}$ & $35^{11}$ & $1650 \pm 800$ \\
\hline Golden figurine, Islamic (IG 1) & 7 & $11-12$ th $\mathrm{AD}$ & 0.85 & $0.9^{14}$ & $0.8^{14}$ & $1800 \pm 1000$ \\
\hline Golden figurine, Islamic (IG 2) & 7 & $11-12$ th $\mathrm{AD}$ & 2.0 & $6.2^{12}$ & $126^{12}$ & $170 \pm 100$ \\
\hline
\end{tabular}

Table 3: Ancient gold objects

Tableau 3 : Objets en or anciens

\footnotetext{
* Time of manufacture adopted before U;Th - dating (BC: before Christ, AD: after Christ); u.k. : origin unknown to us. Samples of the gold objects were obtained from: 1 private ownership; 2 Pieter Meyers (see Table 2), on behalf of a client; 3 Dieter Willers; 4 Alex Kossolapov; 5 Jack Ogden, on behalf of a client; 6 Melanie Roy: 7 Marianne Senn, on behalf of a client; 8 Ernst Pernicka, on behalf of a client.

$\mathrm{U}$ and Th measurements performed by: 9 Urs Krähenbühl (see Table 2); 10 adopted values (Eugster et al., 2009); 11 average values from Urs Krähenbühl and Jan Kramers; 12 Valerie Olive; 13 Ernst Pernicka; 14 Jan Kramers; 15 Stefan Röllin.
} 


\section{Ancient gold objects}

The gold objects that could be confirmed to be ancient are compiled in Table 3. Based on the ${ }^{4} \mathrm{He}, \mathrm{U}$, and Th concentrations, their ages were calculated using the formula

$\mathrm{T}=\left[{ }^{4} \mathrm{He}\right] /\left(3.24 \times 10^{6}[\mathrm{U}]+7.70 \times 10^{5}[\mathrm{Th}]+4.02 \times 10^{3}[\mathrm{Sm}]\right)$

where ${ }^{4} \mathrm{He}$ is expressed in atoms per $\mathrm{g}$ and $\mathrm{U}, \mathrm{Th}$, and $\mathrm{Sm}$ in ppm. The $\mathrm{U}, \mathrm{Th}-\mathrm{He}$ age results are in years. For the derivation of this formula and for the decay constants of the radionuclides and their relative abundances we refer to our previous publication (Eugster et al., 2009). Usually the main contribution of ${ }^{4} \mathrm{He}$ comes from $\mathrm{U}$, whereas $\mathrm{Sm}$ contributes only a few percent to the total He. The estimated U, Th $-\mathrm{He}$ ages are consistent with the presumed date of manufacture of these gold objects. The experimental errors are up to $50 \%$ because in most cases the $\mathrm{He}, \mathrm{U}$, and Th concentrations are very low. The counting statistics for the measurements for each of these elements lead to an uncertainty of about $30 \%$.

In the following, we discuss two objects in more detail: (i) as mentioned in section 2, the result for the signet ring of a Merovingian king was already presented in Eugster $e t$ al. (2009). In the present work, we obtain a more reliable age of $1460 \pm 400$ years, because $U$ and Th concentrations are now available. This age is in good agreement with the time when the kings Childebert I and II lived. (ii) Two different samples of the Islamic figurine were analyzed for $\mathrm{He}$ and chemical elements, and two different $\mathrm{U}, \mathrm{Th}-\mathrm{He}$ ages were obtained. As outlined by Senn et al. (2009), the figurine is characteristic for the Islamic tradition and dated to the $11^{\text {th }}$ or $12^{\text {th }}$ century AD. Based on the trace element pattern, it can be inferred that the figurine derives from the area of Iraq and Syria. The figurine is manufactured from a native goldsilver alloy, using copper as soldering material. The measured alloy compositions of the feet vary considerably. Therefore, it can be assumed that at least two different materials were used to manufacture the figurine or to repair it. Our dating of the figurine provides two dates, one to the period of 1800 \pm 800 years ago, and a second one $170 \pm 100$ years ago (Table 3). The older material belongs to a sample taken from an area between the legs of the trousers, a section of the figurine that is well preserved. The younger material was taken from the spine, where the figurine is strongly damaged and where the elemental composition differs from that of the undamaged parts. It appears that repairs were carried out on the damaged spine in more recent times. In general, the natural scientific study confirms the results of the stylistic study (Senn et al., 2009).

\section{Modern and undatable gold objects}

In Table 4, gold objects are listed that turned out to be modern or were undatable due to a He excess of unknown origin. For three objects, the He concentration was below the detection limit or extremely low, resulting in a modern date. One of these three objects is not specified in Table 4, as the owner did not give the permission to mention the details in this paper. Some objects yielded He concentrations, for which, together with the $U$ and Th concentrations, an unreasonably high $\mathrm{U}$, Th $-\mathrm{He}$ age was obtained. These objects must contain helium that was not completely outgassed when the object was manufactured. Among these objects are samples Java 1-4, for which, in an earlier report to the owners, we estimated an ancient origin. A more critical interpretation, after having found more similar cases

\begin{tabular}{|c|c|c|c|c|c|c|}
\hline Object and origin (sample Nr.) & $\begin{array}{l}\text { btained } \\
\text { from * }\end{array}$ & $\begin{array}{l}\text { Adopted } \\
\text { century * }\end{array}$ & $\begin{array}{c}\mathrm{He} \\
10^{4} \text { atoms } / \mathrm{mg}\end{array}$ & $\begin{array}{c}\mathrm{U} \\
\mathrm{ppb}\end{array}$ & $\begin{array}{l}\text { Th } \\
\mathrm{ppb}\end{array}$ & $\begin{array}{l}\text { Estimated } \\
\mathrm{J}, \mathrm{Th}-\mathrm{He} \text { age }\end{array}$ \\
\hline Large golden plate, origin u.k. (MG 4) & 5 & u.k. & b.d. & $0.5^{14}$ & $0.7^{14}$ & modern \\
\hline $\begin{array}{l}\text { Large plate with } 10 \text { human figures } \\
\text { Liao dynasty, }(083108-1)\end{array}$ & 2 & 10-12th AD & 1.8 & $11^{12}$ & $88^{12}$ & modern \\
\hline \multicolumn{7}{|l|}{ Undatable objects, due to He rich inclusions } \\
\hline Gold object JDM 1, Black Sea, Russia (JDM 2) & 5 & 6th BC & 860 & $5.4^{9}$ & $69^{9}$ & - \\
\hline Gold inlaid leopard, China (080406) & 2 & u.k. & 400 & $12^{15}$ & $3.9^{15}$ & - \\
\hline Necklace of 32 gold beads, Outer Mongolia (3101) & 1) 6 & 4th $\mathrm{BC}$ & 24 & $0.8^{13}$ & $0.3^{13}$ & - \\
\hline Buddha statue Avelokateshvara, Java (Ave 1-4) & p.c. & 13th AD & $7-5000$ & $0.3-0.8^{13}$ & $0.3-0.7^{13}$ & - \\
\hline Gold objects (Java 1-4) & 8 & u.k. & $6-24$ & $0.14-7.12^{13}$ & $0.38-12.2^{13}$ & - \\
\hline
\end{tabular}

Remarks: * see remarks to Table 4; u.k. unknown to us; b.d. below detection limit; p.c. private client.
Table 4: Modern and undatable gold objects Tableau 4: Objets en or modernes et non datables 
of He excesses, led us to the conclusion that the Java 1-4 samples are undatable. This leads us to acknowledge that the $\mathrm{U}, \mathrm{Th}-\mathrm{He}$ dating method presented in this work for detecting forgeries in the market of antique gold objects is still far from being a reliable dating method. The reason for this are the extremely low $\mathrm{He}, \mathrm{U}$ and Th concentrations, which are at the limit of being precisely determined by the presently available techniques. We observed that some antique gold objects contain inclusions, such as micron sized quarz and feldspar grains that did not completely release all He when the gold object was manufactured. Therefore, we plan to search for inclusions by electron microscopic investigations. On the other hand, it appears that in cases where the original material for the production of the gold object was already processed before, the dating method works fine. Examples are the Childebert signet ring, probably produced from Byzantine solidi, and the Napoléon gold coin. Knowing that gold is very often recycled, the determination of its chemical composition is not a final test for authenticating an ancient object, and dating, performed using the method presented in this work, may be necessary.

\section{Acknowledgements}

The authors are greatly indebted to the institutions that supplied the gold samples studied in this investigation: Alex Kossolapov, State Hermitage Museum, St. Petersburg; Pieter Meyers, Los Angeles County Museum of Art; Jack Ogden, Gemmological Association and Gem Testing Laboratory, London; Melanie Roy, TK Asian Antiquities Williamsburg, VA, USA; Marianne Senn, Zentrum für Kulturanalytik, EMPA, Dübendorf, Switzerland; Dietrich Willers, University of Bern. We thank the collaborators, who provided $U$ and Th data in addition to those provided by the co-authors of this paper: Boaz Paz, Curt-Engelhorn-Zentrum Archäometrie, Mannheim, Germany; Urs Krähenbühl, University of Bern; Jan Kramers, University of Bern; Paterno Castillo, Scripps Institution of Oceanography, UCSD, La Jolla, CA. We also thank Arthur Ghielmetti, Armin Schaller and Markus Zuber for their technical assistance.

\section{References}

Eugster, O., 1996. Applications for noble gas analyses of gold. Gold Bulletin 29(3): 101-104.

Eugster, O., Kramers, J. and KräHenbüHL, U., 2009. Detecting forgeries among ancient gold objects using the U,Th $-{ }^{4} \mathrm{He}$ dating method. Archaeometry 51(4): 672-681.

Kossolapov, A.J. and Chugunova, X.S., 2002. Authenticating ancient gold using the U-He radiogenic clock, in R. Van Grieken, K. Janssens, L. Van't Dack, G. Meersman (eds.), Proceedings ART 2002, $7^{\text {th }}$ International Conference on Nondestructive Testing and Microanalysis for the Diagnostics and Conservation of the Cultural and Environmental Heritage, 2-6 June 2002, Congress Centre Elzenveld, Antwerp, Belgium. Antwerp, University of Antwerp, CD-ROM.

Kossolapov, A.J., Ivanov, A.P. and Kuznetsov, P.B., 1999. Helium radiogenic clock for dating of archaeological gold, in W. Mc Crone, D.R. Chartier, R.J. Weiss (eds.), Proceedings SPIE, v. 3315, Scientific Detection of Fakery in Art. San Jose, CA, SPIE, 16-20.

Senn, M., Flisch, A., Eugster, O., Günther, D. and Vonmont, H., 2009. Test report No. 450'588, EMPA Ueberlandstrasse 129, Dübendorf, Switzerland.

Shalem, A., 2002. A note on a unique Islamic golden figurine. Iran 40: 173-180.

WeBER, A.G., (ed.), 2007. Der Childebertring und andere frühmittelalterliche Siegelringe. Köln, Weber. 
